\title{
Anti-intellectual Policies, the Weak President, and the Establishment: Assessment of the Effects of Trump- style Populism (2016-2020)
}

\author{
Ming $\mathrm{Mo}^{1, \mathrm{a}}$ \\ ${ }^{1}$ Department of Government \& International Studies, Hong Kong Baptist University, Hong Kong 999077, Hong Kong \\ amoming0328@126.com
}

\begin{abstract}
The approaching the American Presidential Election in 2020 has attracted attention and discussion about Trump and Trump-style populism, which has been spreading in the U.S. since 2016. This paper focuses on the quantitative analysis of specific indicators to evaluate the effects of Trump-style populism and finds that the theoretically beneficial groups have not benefited from the Trump-style populism governance. Compared with traditional literature on populism, this paper increases the analysis and comparison of the actual effect of Trump-style populism in the term and extended analyzes of the patriarchism dimension, which can deepen the understanding and research on the characteristics of Trump-style populism. Moreover, this paper also has some enlightenment to the prediction of the 2020 American Presidential Election. Because President Trump's victory in 2016 included the support of many working-class whites and the men, it is not certain that after four years of Trump-style populism governance, whether the white class will still support him in the election or not.
\end{abstract}

Keywords: Trump, Populism, Racism, Patriarchism, American Presidential Election

\section{INTRODUCTION}

With the approaching of the American Presidential Election in 2020, Trump and his populism have attracted attention and discussion from all sides, which has been spreading in the U.S. since 2016. According to the Britannica (2020), populism will advocate or declare for the ordinary citizens, which criticizes political representation and anything mediating between the people and their leaders or governments to maximize the power and rights of ordinary citizens. However, the concept of "people" here is limited to a narrow sense, which can be defined according to class, race, and other factors (Mudde\& Kaltwasser, 2017). In this way, populism is essentially the opposite of pluralism, which is the key element of democracy. In addition to the general characteristics of populism, Trump-style populism always associates with racism and patriarchism, which shows as the oppression and discrimination to the people of color and women, and can be observed in the speeches and policies of Trump. In the context of the United States, Trump-style populism is aimed at the benefit of the white class and the men. Through the above description and analysis of Trump-style populism, it can be seen that the connotation of this concept is also quite different from populism in the general sense. And the concept of populism in today's American society is inevitably associated with racism and patriarchism with outstanding Trump's subjective color. In addition, racial discrimination and gender discrimination, as a legacy of history, are the trigger point of many conflicts in today's American society.

Populism banner has been an important feature of Trump's propaganda and administration from the last election campaign to his four-year term in office. Under such a political condition, the white and men, as the theoretically beneficiary groups of Trump-style populism, whether have made more significant changes and improvements in the quality of life and economic conditions compared with non-populist beneficiaries (such as the black and women) and the root causes behind the result. For this research question, it can be concluded by comparing the data in income, insurance, and GDP from different categories (such as race and gender) and getting a data result of relative gains between different categories. Furthermore, a case study can help with exploring the reasons for the result. After data analysis and case study, this paper finds that the 
theoretically beneficial groups have not benefited from the Trump-style populism.

Compared with other studies on Trump-style populism, this paper increases the analysis and comparison of the actual effect of Trump's populism in the term and extended analyzes of the patriarchism dimension, which can deepen the understanding of the Trump-style populism. On the realistic level, this paper also has some enlightenment to the prediction of the 2020 American Presidential Election. Because Trump's victory in 2016 included the support of working-class whites, it is not certain that after four years of Trumpstyle populism governance, whether the white class will still support him in the election.

The paper is consisting of five parts as followed. The first section contains the literature review about the definition, motivation, and effect of populism. And the second section gives a clear research framework that Trump-style populism has not benefited the white and men. The third part takes data analysis to support the research conclusion. The fourth part gives a case study about the repeal of the ACA Bill. And the last is the conclusion.

\section{LITERATURE REVIEW}

In the wake of Trump's victory in the 2016 Presidential Election, the U.S. has seen a rising tide of populism. The upcoming 2020 Election has put the concept of populism at the forefront of public opinion. Many scholars have conducted extensive research and discussion on populism and its related influencing factors. The literature review part will analyze and summarize some recent studies on the definition, motivation, and multifaceted effects of populism.

The research on populism is originated in the 19th century. According to the Britannica, populism will advocate or declare for the ordinary citizens, which criticizes political representation and anything mediating between the people and their leaders or governments to maximize the power and rights of ordinary citizens. In contemporary political theories, populism is associated with political autocracy and revolves around a leader. That is because the concept of "people" here is limited to a narrow sense, which can be defined according to class, race, and other factors. However, populism is often seen as a way for politicians to pander to common citizens. In the era of the Internet, social media is an important platform for populists to freely express their ideology and spread their message, which fits Trump's propaganda and implementation style (Engesser et al., 2017). And Taggart (2002) argued that the "people" is the core of the populism concept, and another crucial point is the rejection and hostility to the representative politics.

The definitions mentioned above are confined to the general chrematistics of populism, while the Trump-style populism is a special case. Jones et al. (2017) evaluated Trump-style populism as the resurgent of Jacksonianism and ideology of unilateralism expressing as "America First". And Bonikowski (2016) argue that Trump's radical rightwing populism contains elements of the racism and the mobilization that split nationalism, which is consistent with Bonikowski (2016) and Patenaude (2018) that Trump-style can be considered as populism plus racism.

Meanwhile, the motivations behind the rise of populism are contested, which can be broadly divided into the following: economy recession with economic inequality, social order breakdown, supporting targeted people, charismatic leaders, and other related factors. First, Bonikowski (2016) has believed that the aggravation of economy and trade was one of the important reasons. In addition, Connor (2017) has also built the connection between economic inequality and the rise of populism. But Patenaude (2018) has partially rejected the traditional economic position motivation that the role of economic anxiety and economic crisis in racial resentment and racially motivated voting behavior needs further study to get a conclusion. Second, according to Deiwiks (2009), the breakdown of social order is a significant incentive of populism. Taking the United States into consideration, after the 2008 Financial Crisis, its social order has been damaged comparing with the conditions before the crisis. Literatures of the Third category are about analyzing the targeted people. Spruyt et al (2016) have found that populism is rooted in dissatisfaction with politics and society, which can easily help with getting strong support for stigmatized groups who cannot find a positive social identity. In addition, as for the white people, the core role of American populism, Patenaude (2018) has stated that populism was composed of white people, rural people, and economically oppressed reactionaries, while Mondon and Winter (2018) have argued that the election of Trump, a populist President, could not be regarded as the revolt of the working white class. Fourth, Trump has a special characteristic in the leader image. Brandt (2020) has analyzed the characteristics of Trump-style populism at the media level, which has shown the characteristics of his populist mood and performance with the perspective of populism and media.

Scholars have also analyzed the effect of populism, especially the living condition of black groups in recent years, including their income, social status, psychological status, and other factors. Chetty et al. (2019) have agreed that blacks and Indians in the US had much less upward mobility and much more downward mobility than whites until 2015, which is also an important reason for the persistent gap between generations. According to Chetty et al. (2019), even for boys who grew up in the same neighborhood, the gap between blacks and whites persisted. If taking into account their parents' income, 99 percent of black boys 
in the census district earned less as adults than whites. On the side, Assari et al. (2018) has shown that minorities enjoy smaller health benefit than whites in terms of social and economic status (SEP). To sum up, black people in the U.S. still suffer from unequal treatment and survival plight.

There is a mass of high-quality researches concerned with populism plus racism issues. However, there are still some limitations in these papers, for example, lack of research on the combination of populism and patriarchism in the United States. Moreover, the scholars mentioned above have paid more attention to the characteristics and connotations of Trump-style populism in the 2016 election process without analyzing the practical effects of Trump-style populism during his reign. And these limitations will be the focus of this paper.

\section{THE RESEARCH FRAMEWORK: ASSESSMENT OF THE EFFECTS OF TRUMP-STYLE POPULISM}

Trump has made some political promises to win votes and supporters in the 2016 election. However, it can be observed that Trump-style populism has not benefited theoretically beneficial groups. The promises made by Trump during the election campaign cannot determine the implementation effectiveness of the final political decisions. Because the implementation of political policies would be influenced by the rational choice of politicians, the authority of decision-making bodies, the social conditions and restrictions, etc. With the 2020 Presidential Election coming, to achieve his fundamental goal of reelection, the impact of Trump's policies in the first term and the probable impact on the next possible presidency have become a significant political focus.
Given the path through which Trump-style populism comes into play, the following should be considered: the context and motivation of Trump-style populism, the way of its implementation, and the actual results.

First, the reason why Trump-style populism can attract a large number of white working-class men and especially gaining support from the Midwest states is the fact that white working-class men and the "rust belt states" have declined in the U.S. in recent years (Steff \& Tidwell, 2020). Based on data from the Center for American Progress, the wealth is increasingly concentrated at the top, where the top 10 percent of Americans in 2016 accounted for more than two-thirds of total wealth. At the same time, according to Glasser and Thrush (2016), Trump's call to working-class white Americans not only aroused racial tensions but also increased the working-class whites' dissatisfaction with the greater influence of globalization and the governance of the elite political hierarchy. In this way, the Trumpstyle populism is involved in some different theoretically beneficial groups, who are the targeted electorates of Trump. These can be considered as the white people, the male citizens, and the supporting states. Based on the above analysis, Trump's supporting voters are specific and targeted, who have their eager demand for Trump's presidency.

Second, Trump-style populism is largely implemented through bills and executive orders. Trump has changed dramatically both domestic and international policies since taking office. Domestic policy reform mainly covers health care, labor, environment, taxation, and finance, while international policy reform mainly focuses on trade policies (Bown, 2017). Typical bills and orders are shown as examples below:

\begin{tabular}{|c|c|c|c|}
\hline Title & Date & Category & Content \\
\hline $\begin{array}{l}\text { Minimizing the Economic } \\
\text { Burden of the Patient } \\
\text { Protection and Affordable } \\
\text { Care Act Pending Repeal }\end{array}$ & $01 / 20 / 2017$ & $\begin{array}{l}\text { Executive } \\
\text { Order } 13765\end{array}$ & $\begin{array}{l}\text { Minimizing the Economic Burden of the Patient Protection } \\
\text { and Affordable Care Act Pending Repeal: } 1 \text {. Encourage } \\
\text { the development of free and open markets between states } \\
\text { to provide commercial health care services and health } \\
\text { insurance } 2 \text {. Not intend to create any rights or benefits }\end{array}$ \\
\hline $\begin{array}{l}\text { Withdrawal of the United } \\
\text { States from the Trans- } \\
\text { Pacific } \\
\text { Negotiations } \\
\text { Agreement }\end{array}$ & $01 / 23 / 2017$ & Memorandum & $\begin{array}{l}\text { The United States is committed to creating fair and } \\
\text { economically beneficial trade agreements, which are } \\
\text { based on a one-to-one (or bilateral) basis. The United } \\
\text { States will withdraw permanently from the TPP and, if } \\
\text { possible, begin bilateral trade talks to promote American } \\
\text { industry, protect American workers and raise wages for } \\
\text { Americans. }\end{array}$ \\
\hline $\begin{array}{l}\text { H.R. } 1 \text { - An Act to provide } \\
\text { for reconciliation pursuant } \\
\text { to titles II and V of the } \\
\text { concurrent resolution on } \\
\text { the budget for fiscal year } \\
2018 \text {. }\end{array}$ & $09 / 11 / 2017$ & bill & $\begin{array}{l}\text { In this reference report mainly involves the individual tax } \\
\text { system reform, the business tax reform, the international } \\
\text { tax regulation, the joint explanatory statement and so on } \\
\text { part. Overall, the report proposes tax reforms that would } \\
\text { take the lower rates and lower interest rates for } \\
\text { individuals, families and businesses. At the same time, the } \\
\text { domestic tax reform of the United States also has an } \\
\text { inevitable relationship with international trade and } \\
\text { multinational enterprises. }\end{array}$ \\
\hline
\end{tabular}




\begin{tabular}{|c|c|c|c|}
\hline $\begin{array}{l}\text { Border Security and } \\
\text { Immigration Enforcement } \\
\text { Improvements }\end{array}$ & $25 / 01 / 2017$ & $\begin{array}{l}\text { Executive } \\
\text { Orders } 13767\end{array}$ & $\begin{array}{l}\text { (a)secure the southern border of the United States through } \\
\text { the immediate construction of a physical wall on the } \\
\text { southern border, monitored and supported by adequate } \\
\text { personnel so as to prevent illegal immigration, drug and } \\
\text { human trafficking, and acts of terrorism; } \\
\text { (b) detain individuals apprehended on suspicion of } \\
\text { violating Federal or State law, including Federal } \\
\text { immigration law, pending further proceedings regarding } \\
\text { those violations; } \\
\text { (c) expedite determinations of apprehended individuals' } \\
\text { claims of eligibility to remain in the United States; } \\
\text { (d) remove promptly those individuals whose legal claims } \\
\text { to remain in the United States have been lawfully rejected, } \\
\text { after any appropriate civil or criminal sanctions have been } \\
\text { imposed; } \\
\text { (e) cooperate fully with States and local law enforcement } \\
\text { in enacting Federal-State partnerships to enforce Federal } \\
\text { immigration priorities, as well as State monitoring and } \\
\text { detention programs that are consistent with Federal law } \\
\text { and do not undermine Federal immigration priorities. }\end{array}$ \\
\hline $\begin{array}{l}\text { Adjustments of Certain } \\
\text { Rates of Pay }\end{array}$ & $28 / 12 / 2018$ & $\begin{array}{l}\text { Executive } \\
\text { Order } 13856\end{array}$ & $\begin{array}{l}\text { It adjusts the following part: Statutory Pay Systems, Senior } \\
\text { Executive Service, Certain Executive, Uniformed } \\
\text { Services, Locality-Based Comparability Payments, } \\
\text { Administrative Law Judges, Effective Dates, Prior Order } \\
\text { Superseded }\end{array}$ \\
\hline $\begin{array}{l}\text { Combating Public Health } \\
\text { Emergencies and } \\
\text { Strengthening National } \\
\text { Security by Ensuring } \\
\text { Essential Medicines, } \\
\text { Medical } \\
\text { Countermeasures, and } \\
\text { Critical Inputs Are Made in } \\
\text { the United States }\end{array}$ & 06/08/2020 & $\begin{array}{l}\text { Executive } \\
\text { Order } 13944\end{array}$ & $\begin{array}{l}\text { The United States must protect our citizens, critical } \\
\text { infrastructure, military forces, and economy against } \\
\text { outbreaks of emerging infectious diseases and chemical, } \\
\text { biological, radiological, and nuclear (CBRN) threats. } \\
\text { Maximizing Domestic Production in Procurement. }\end{array}$ \\
\hline
\end{tabular}

Sources :

https://www.federalregister.gov/documents/2020/08/14/ 2020-18012/combating-public-health-emergencies-andstrengthening-national-security-by-ensuring-essential

https://www.federalregister.gov/documents/2017/01/25/ 2017-01845/withdrawal-of-the-united-states-from-thetrans--pacific-partnership-negotiations-and-agreement

https:/www.congress.gov/congressional-report/115thcongress/house-report/466/1 ?overview $=$ closed

Third, there are two main reasons why Trump-style populism policies failed to produce the desired effect or even not entered the implementation stage: Trump's personal character with mature political system in the U.S., and populism lacking practicality. As for the personal factor, Trump as the principal part of the populism motivation has taken populism as governance standards and attempt to shape his image in his supporting voters as the reformers and the image of "Christ", while Trump lacks the implementation authority and his own rational choice hinder the populism benefiting the theoretically beneficial groups. Trump tried to take the populism position into his policies, but in the process of such policies implementation, many problems appeared because of the insufficient authority, which is subject to the American political feature like the balance of power system. This is highlighted in the following aspects: the low confidence of American citizens in Trump and his policies, the difficulty of achieving populism policy coherence within the Republican Party, and external factors such as interest group limited. Different groups achieve a complex balance of power in the U.S, which to some extent limited the authority of Trump's policy decision-making and implementation. In this way, Trump has no choice but to make a rational choice to achieve his fundamental goal of winning votes. On the one hand, Trump stuck to his populism stance to shore up the 2016 voter base. On the other hand, Trump has shifted the balance between appeasing and preserving voters by taking a tough foreign policy and transferring contradictions to other actors and institutions. Furthermore, populism itself is anti-intellectual that can only be used as a campaign gimmick without practice, which means that the combination of populism and policy cannot achieve practical results. Populism itself contains protectionism and political discrimination, which is difficult to achieve in today's globalized and pluralistic society. Trump-style populism over-considers protecting the domestic economy while ignoring the relatively greater losses than trade protectionism may bring in, which cannot have the value in the practice level for the theoretically beneficial groups. 


\section{DATA ANALYSIS}

The data takes the race and gender-related to populism as independent variables, and income, insurance, and state GDP as dependent variables (20082018). In these variables, income, insurance coverage, and state GDP (classified according to whether the states supported Trump in 2016) can be used as measures of benefits, which relate to the individual economic level, social welfare, and regional economic level. It can be concluded that the potential beneficial group does not benefit from Trump-style populism with the data comparison between different variables.

\subsection{The Income}

The income is a significant index to measure the living quality of the citizens. There will be an analysis of the absolute amount of income and the growth rate of income. In terms of the absolute amount of income, during the Trump administration, no matter white, black, Asian, male or female, the income showed an increasing trend. However, the rank of the income is that the Asian race occupied the first following with the white and the black, and that of males was higher than that of females was always maintained. At the same time, from the perspective of absolute income difference, the Trump administration has maintained the trend of increasing the income gap between race and gender under Obama, and there is no obvious change that can prove that potential beneficiaries gain a comparative advantage. At the same time, the income gap between the Asian and the white population shows a rapidly expanding trend (the income of the Asian is greater than that of the white).

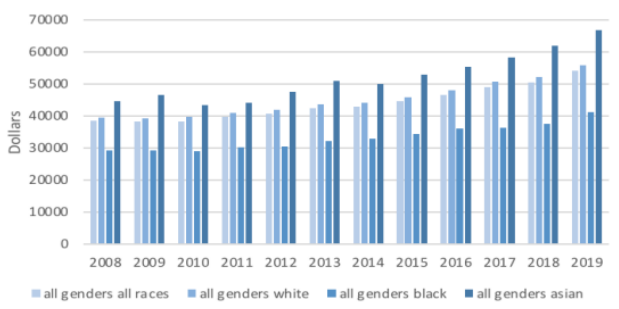

Figure 1 Absolute income by races (2008-2019)

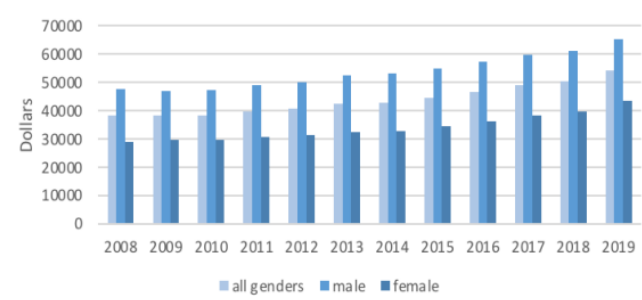

Figure 2 Absolute income by genders (2008-2019)

Source: https://www.census.gov/data/tables/timeseries/demo/income-poverty/cps-pinc.html Retrieved September 23, 2020
In terms of the growth rate of income, during the Trump administration, the income of white, black, Asian, male, and female has been trending in a positive direction. The growth rate of whites' income, the growth rate of white income shows a certain advantage compared with the growth rate of 0.052331 of the whole species, and 0.013052 of black income in 2016-2017. However, in the following year's income growth rate, the whites' income growth rate of growth dropped sharply to 0.025859 , which was lower than the overall rate of 0.029131 , 0.028104 for blacks, and 0.063996 for Asians. And even for the growth rate of 2018-2019, the rate of the black increased to 0.101486 , while the white only had 0.070049 . It can be seen that the white only had a high growth rate in a short term (only for 2016-2017), where the black had a higher growth rate in the long term (to the nowadays latest data update-2019). So, the change in the data can be interpreted as a short-term strategy to stabilize his supporters in the early days of the Trump presidency, only to return to the early levels the following year. And even after 2018, the growth rate of black people is higher than the average and the white people. At the same time, it can be observed that the income growth rate of women is consistently higher than that of men, which has even not been achieved under Obama. Besides the Chi-Square test also proved that there is no significant difference in the income structure of different races and genders in the two time periods. It means that categories of race and gender remain in the overall direction of 2009-2017 (like the reasons mentioned above, 2017 did not be categorized in the Trump's governance), which is a testament to the fact that there has been no significant change in Trump's governance.

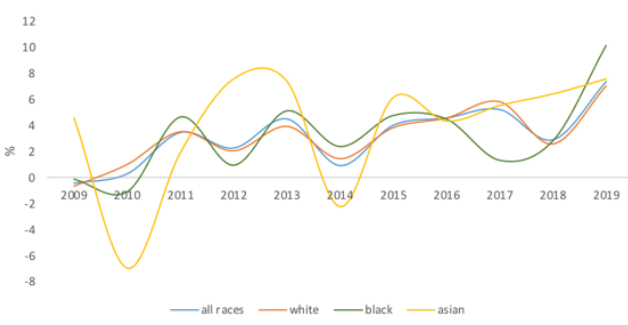

Figure 3 Annual growth rate of income by races (2009-2019)

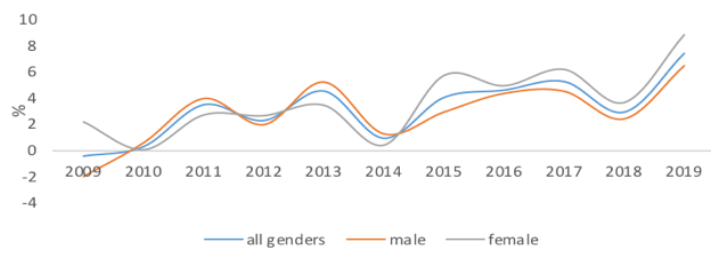

Figure 4 Annual growth rate of income by genders (2009-2019)

Source: Ibid 
Chi-Square test: The Chi-Square test of income growth rates

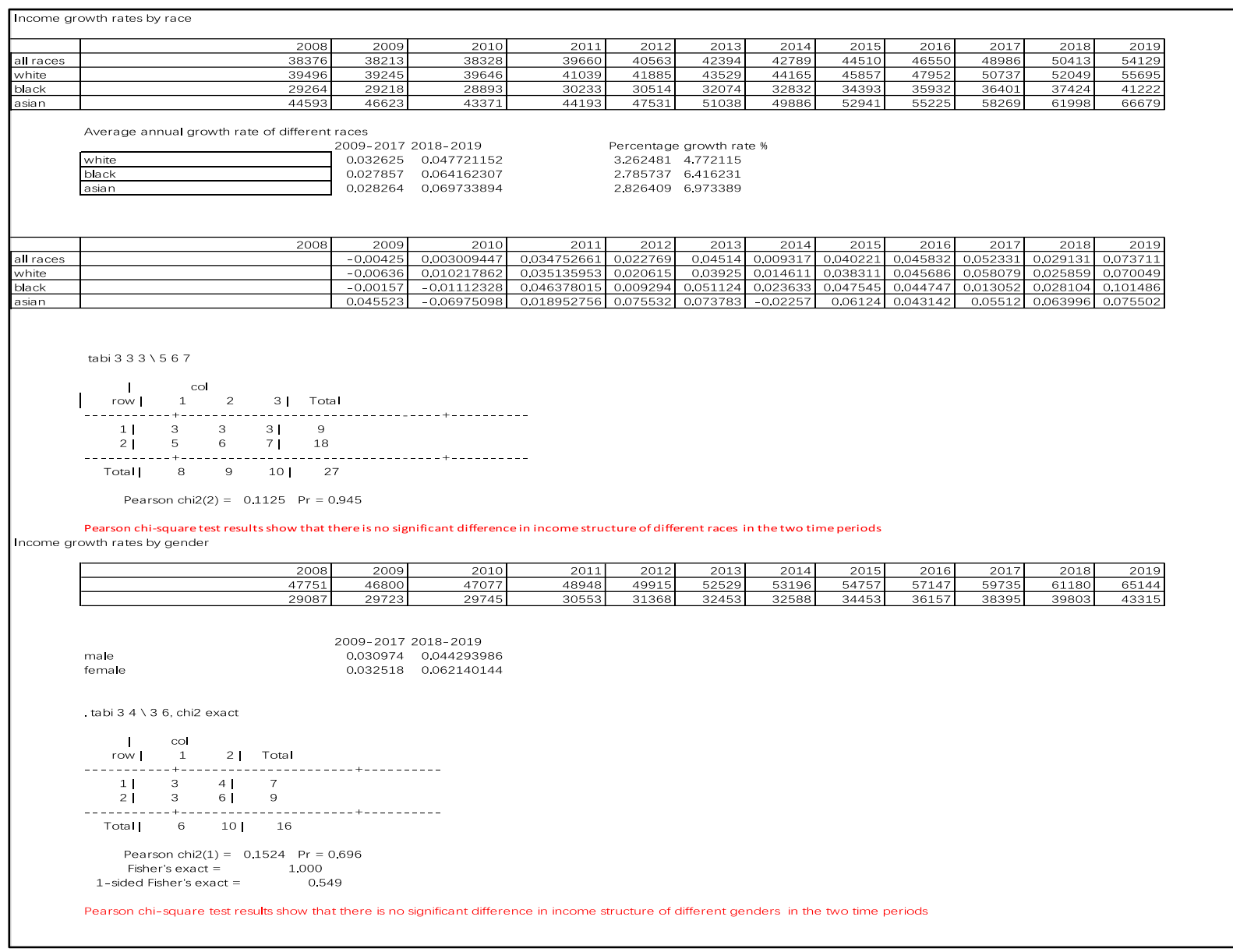

Sources :

https://www.federalregister.gov/documents/2020/08/14/ 2020-18012/combating-public-health-emergencies-andstrengthening-national-security-by-ensuring-essential https://www.federalregister.gov/documents/2017/01/25/ 2017-01845/withdrawal-of-the-united-states-from-thetrans--pacific-partnership-negotiations-and-agreement

https://www.congress.gov/congressional-report/115thcongress/house-report $/ 466 / 1$ ? overview $=$ closed

\subsection{The Insurance}

The insurance is crucial protection of the citizen's life, where it's condition should be considered as the impact index of the living quality. Insurance penetration in the United States reached a high level in 2016 as a result of Obama's ACA law. In 2017, insurance penetration of all races and genders showed a trend of decline. In 2018, the above categories showed a simultaneous trend of recovery. Specifically, insurance penetration for Asians fell in 2016 but rose from 2017 to 2018. After Trump took office, the insurance coverage rate of the female was always higher than that of the male, and the difference showed an increasing trend. And for the race factor, there is no obvious trend difference comparing with the Obama's period.

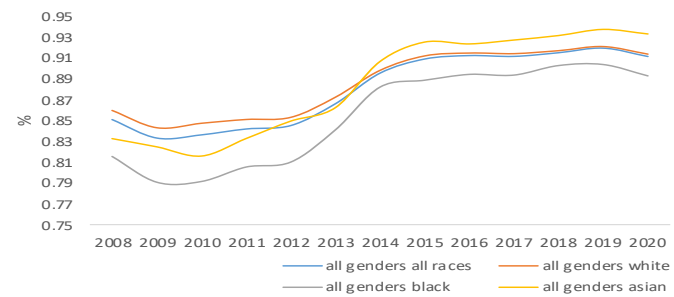

Figure 5 Insurance ownership rate by races (20082019)

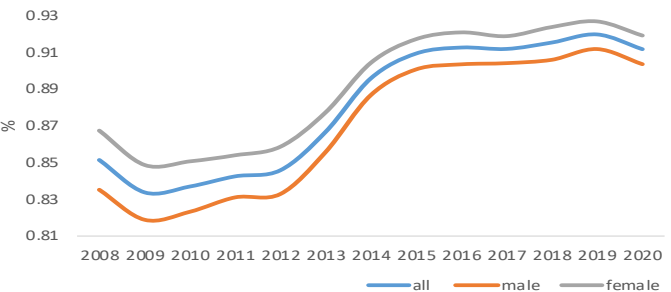

Figure 6 Insurance ownership rate by genders (20082019) 
Source: Ibid

\subsection{The Supporting States of Trump}

Most of the states that voted for Trump in 2016 were Midwestern states, which can also be called the Manufacturing Belt. In the face of Trump's populism politics and campaigning style, these states chose to back him and his pledge to "Make the America Great Again". By 2019, the economic growth of the Trump-voting states, which can be measured in state GDP, has not achieved the revitalization goal.

In terms of absolute economic quantity, the total economic aggregate of these states is constantly growing, but at the same time, the economy of all other states shows a development trend. Meanwhile, their share of the U.S. economy has not changed significantly since 2016, with each holding steady at around 49 percent.

As for growth rates, all of the States that voted for Trump showed generally higher growth rates. Although the growth rate of all the states that voted for Trump was generally higher, the economic situation of these states showed a recovery in the late Obama administration, which means that the economic recovery point of these states appeared earlier than 2016 and it was not Trump that brought economic recovery to these states. Furthermore, comparing these states with the U.S. as a whole, it showed that they did not gain more economic advantages. From 2016 to 2019, the rate of economic growth in states that supported Trump was substantially lower than that of the United States as a whole, which sustained the economic conditions of the Obama administration. At the same time, there was no significant difference in economic growth rates between states that supported Trump and those that did not. Therefore, it can be seen from the above data that the states supporting Trump did not achieve higher economic development achievement after Trump took office and became the actual beneficiary group, and there was no obvious change and improvement between Trump and Obama.

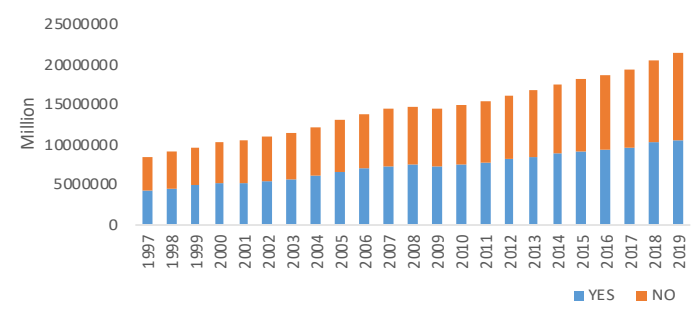

Figure 7 The GDP of supporting states and nonsupporting states (1997-2019)

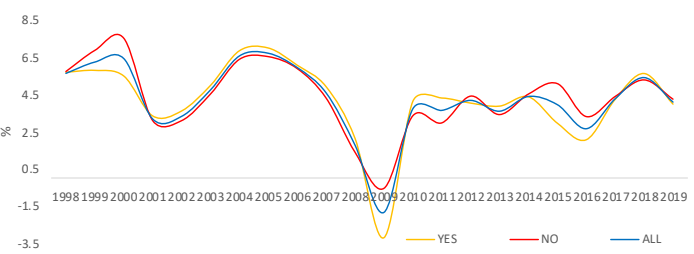

Figure 8 The annual GDP growth rate of supporting states and non-supporting states (1998-2019)

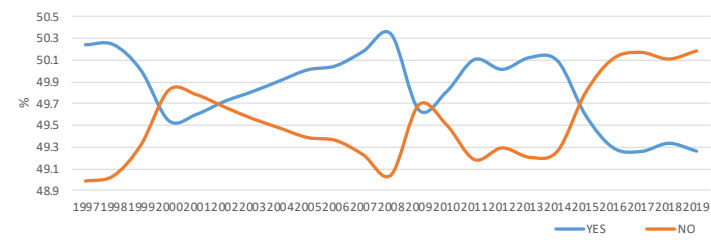

Figure 9 The GDP share of supporting states and nonsupporting states (1997-2019)

Source: Ibid

\section{CASE STUDY}

The relationship between ACA and populism should be clarified before analyzing Trump's intention to abolish the ACA. From the policy definition, according to the Buchmueller and Levy (2016), the Bill in the Obama era provides millions of Americans with Affordable Health insurance by insured persons with low-income coverage, subsidies for private coverage who are a vulnerable group in the society, which has made more than 20 million people get health care. In addition to the meaning of the policy itself, according to the New York Times reported in 2014, the real beneficial group of ACA are the black, and Spanish, and people in the vast rural areas who are mainly concentrated in 18 to 34 years old, for example, rural Arkansas, south Texas, Kentucky, and other regions have high insurance increase rate. At the same time, women also benefit more from the ACA than men. It can be seen from the above that ACA's beneficial groups are at odds with the target beneficial group of Trump-style populism. So, Trump took this as an attractive promise to his voter, which was a strategy of the election and would take the form of an executive order or even an exit from an alternative plan to repeal the ACA. When Trump's intention turned into the executive order, some interest bodies are involved in this process, who can be classified into American citizens, interest groups, and the authority including the parties, congress, or other institutions.

For the situation of American citizens, the ACA has wide and complex beneficial groups (including populism beneficial groups that support Trump and populism nonbeneficial groups that are socially disadvantaged in the traditional sense), which caused the interests of different beneficial groups in the act are intertwined and contain 
each other, making it difficult to promote the reform of the act. This is because the gap between the rich and the poor in America is not divided according to race, and on the contrary, the economic level of some white men is not ideal. In this way, the repeal of ACA will shake the interests of some white voters.

Thus, the above background and characteristics are reflected in the overall American electorate showing as followed phenomena: a majority of supporting ACA Americans, a large number of demonstrations against ACA repeal, and the underlying reasons for the ACA repeal process not being moved forward. First, according to 2019, KFF Health Tracking poll found an overall increase in Americans' favorable opinion of the 2010 Patient Protection and Affordable Care Act, it has shown that more than half of the public ( 52 percent) approved of the ACA, but only 41 percent disapproved of the law. Second, at the same time, there have been massive people's demonstrations against ACA repeal where according to a Reuters report from March 2017, supporters of the health care bill rallied across the country to protest President Trump and Republican congressional leaders plans to repeal the ACA. From the evidence shown above, the mass base of supporting the abolishment of ACA is weak and inadequate. Third, however, it may be confusing that why the revolt and dissatisfaction of people can prevent the abolishment of the ACA but cannot block Trump from becoming President in 2016, which can be considered as underlying reasons for the ACA repeal process not being moved forward. On the one hand, Trump's victory in the 2016 election not only due to the Trump supporters, which rooted in and came into being form the illness of American society and Trump's political charm but also because of the specific electoral system of the United States, which made Trump win the election even though Hillary has more support from the American people. This means that in American society, there are a large number of people against Trump, who cannot directly block Trump's campaign due to the effect of the electoral college. On the other hand, Trump's ultimate and fundamental goal is to get votes and win elections, which means he will spend more on various inputs and efforts to achieve this goal, while the ACA repeal plan is a policy after Trump took office. It can be seen from the full text of the description, the Trump to achieve the goal of abolishing the ACA needs to overcome larger resistance and cause a certain loss. So in the face of this dilemma, the Trump to make rational choices, gave up the continuous efforts on the abolition of ACA, but choosing to transfer of contradictions and problems, such as putting forward a radical international policy or laying the responsibility to the court (2020), to pacify the supporters of his constituency and further strive for the support of voters who against him.

For the interest groups, it can be seen that there are hundreds of interest groups supporting the ACA, which to some extent can block the implementation of opposition policies with the close association between the political policies and the economic condition. According to Congressman Jim Cooper government website, these interest groups include the seniors, business groups, newspaper editorial boards, religious groups, minority or ethnic groups, health care, and medical associations, hospitals, insurance, union, and others, such as Alliance for Retired Americans, Small Business Majority, Academic Medical Centers and humorous supporting interest groups. On the one hand, interest groups can offer "carrots" in the form of political cover, which is intended to help the party they support spread its message to voters. On the other hand, interest groups can use "sticks" or threats to warn and compel members to support or oppose a policy or bill. Besides, according to Reynolds (2017), the effectiveness of interest group participation is also affected by the Republican party's specific procedural strategy, which uses the budget reconciliation process. At the same time, the ability of interest groups to participate will be affected by the speed of the process, where Hall and Reynolds (2012) proved that it takes a certain amount of time for interest groups to carry out effective external lobbying. With the interference and lobbying of interest groups, Trump's plan to dismantle the ACA is difficult to achieve "smoothly" because the economic power and social influence of the interest groups involved are enormous.

For the authority, the current policy decision-making system and party system in the United States can largely hinder the adoption and implementation of policies that differ from their positions, which includes the irrational and anti-intellectual policies of populism. Among all parties, $83 \%$ of Democrats approve of ACA, compared with about $52 \%$ for independents and a much smaller $22 \%$ for Republicans. As a replacement for the ACA, Trump introduced 'The American Health Care Act of 2017', which was defeated in the Republican-led Senate by a vote of 51-49. At least three Republicans, John McCain, Susan Collins, and Lisa Murkowski, voted against the bill. McCain, as a Republican senator from Arizona, has always been deeply conflicted with Trump, and this contradiction is more obvious in the vote of the health care bill. Meanwhile, in the global context of COVID-19 in 2020, 18 Republican states, led by Texas, and the Trump administration, recently filed a petition to the Supreme Court to invalidate the entire Affordable Care Act, where they aimed at getting the power from the court to repeal the ACA. However, until now, there was no effective feedback from the Supreme Court. In this way, neither the ACA repeal nor its replacement will take effect without a united Republican base, the congress, and even the court.

It can be seen from the above evidence that the original reason for the failure of ACA repeal is due to the mature political system in the United States. Although 
the President has the intention to make change, many groups have the power and the right to prevent the policies from achieving the target if the policy is irrational or anti-intellectual.

\section{CONCLUSION}

It can be concluded that that the theoretically beneficial groups did not benefit from the governance of Trump-style populism. The data analysis has shown that the beneficial groups of the white, and men, and the Manufacturing Belt compared with the remaining groups do not have the extra benefit in the income, insurance, and the state GDP.

The reasons why the Trump-style populism cannot benefit the theoretically beneficial group are focusing on the followed reasons. First, the reason why Trump-style populism can attract a large number of white workingclass men in the United States and especially gaining support from the Midwest states is the fact that white working-class men and the "rust belt states" in the United States have declined in recent years. Second, there are two main reasons why populism policies failed to produce the desired effect or even not achieved the implementation stage: Trump's personal factors and the lack of practicality of populism. On the one hand, Trump has the motivation taking the populism as governance standards and attempts to shape his image in his supporting voters as the reformers and the image of "Christ", while he lacked decision-making capability and implementation of authority and the characteristics of his own rational choice hinder the populist benefiting the theoretically beneficial groups. On the other hand, populism itself is anti-intellectual, which can only be used as a campaign gimmick or campaign strategy without practice, and which means that the combination of populism and policy cannot achieve practical results. However, in the process, however, Trump may shift the unfulfilled campaign promises and actual policy effects from himself to other events or authorities in order to maintain and win more voters' trust to win re-election. In fact, Trump has tried to defuse the conflict by shifting it to international issues such as Sino-American trade disputes and shifting the responsibilities to other authorities.

\section{REFERENCES}

[1] Bonikowski, B. (2019). Trump's Populism: The mobilization of nationalist cleavages and the future of US democracy. When Democracy Trumps Populism: European and Latin America Lessons for the United States, edited by K. Weyland and R. Madrid, 110-131.

[2] Brandt, S. L. (2020). Donald Trump, the Reality Show: Populism as Performance and
Spectacle. Zeitschrift für Literaturwissenschaft und Linguistik: Lili, 50(2), 303-321.

[3] Buchmueller, T. C., Levinson, Z. M., Levy, H. G., \& Wolfe, B. L. (2016). Effect of the Affordable Care Act on racial and ethnic disparities in health insurance coverage. American journal of public health, 106(8), 1416-1421.

[4] Callaghan, T., \& Jacobs, L. R. (2016). Interest group conflict over Medicaid expansion: The surprising impact of public advocates. American journal of public health, 106(2), 308-313.

[5] Center, H., Woods, C. A., Manchikanti, L., \& Purdue Pharma, L. P. (2017). A critical analysis of Obamacare: Affordable care or insurance for many and coverage for few. Pain Physician, 20, 111-138.

[6] [6] Chetty, R., Hendren, N., Jones, M. R., \& Porter, S. R. (2020). Race and economic opportunity in the United States: An intergenerational perspective. The Quarterly Journal of Economics, 135(2), 711-783.

[7] Complete List of Groups that Support this Health Care Bill. (April 04, 2012). Retrieved October 01, 2020, from

https://cooper.house.gov/media-center/pressreleases/complete-list-of-groups-that-support-thishealth-care-bill

[8] Duncan, P., \& Levett, C. (2016, November 11). Clinton won more votes; Trump won the election. And it's not the first time. Retrieved October 01, 2020 , from

https://www.theguardian.com/news/datablog/2016/ nov/11/clinton-won-more-votes-trump-won-theelection-and-its-not-the-first-time

[9] Engesser, S., Ernst, N., Esser, F., \& Büchel, F. (2017). Populism and social media: How politicians spread a fragmented ideology. Information, communication \& society, 20(8), 1109-1126.

[10] GLASSER, S., \&amp; THRUSH, G. (2016). What's Going on With America's White People? Retrieved October 1, 2020, from

https://www.politico.com/magazine/story/2016/09/ problems-white-people-america-society-class-race214227

[11] Hall, R. L., \& Reynolds, M. E. (2012). Targeted issue advertising and legislative strategy: The inside ends of outside lobbying. The Journal of Politics, 74(3), 888-902.

[12] Jones, D. M., \& Khoo, N. (2017). Donald Trump and the new Jacksonians. Policy: A Journal of Public Policy and Ideas, 33(1), 42. 
[13] Keith, K. (2020, June 26). DOJ, Republican AGs Ask Supreme Court to Strike Down ACA. Retrieved October 01, 2020, from

https://www.healthaffairs.org/do/10.1377/hblog202 00626.180922/full/

[14] KFF Health Tracking Poll: The Public's Views on the ACA. (2020, September 30). Retrieved October 11, 2020, from https://www.kff.org/interactive/kffhealth-tracking-poll-the-publics-views-on-the-aca/

[15] Kollman, K. (1998). Outside lobbying: Public opinion and interest group strategies. Princeton University Press.

[16] Mondon, A., \& Winter, A. (2019). Whiteness, populism and the racialisation of the working class in the United Kingdom and the United States. Identities, 26(5), 510-528.

[17] Mudde, C., \& Kaltwasser, C. R. (2017). Populism: A very short introduction. Oxford University Press.

[18] Murad, Y. (2020, March 23). Despite a Decade of Challenges, ACA Has Support Among 55\% of Voters.

Retrieved October 01, 2020, from

https://morningconsult.com/2020/03/23/despite-adecade-of-challenges-aca-has-support-among-55of-voters/

[19] Patenaude III, W. (2019). Modern American populism: Analyzing the economics behind the "silent majority," the tea party, and trumpism. American journal of economics and sociology, 78(3), 787-834.

[20] Reynolds, M. (March 07,2017). On the ACA, don't just watch Congress-watch interest groups too. Retrieved October 01, 2020, from

https://www.brookings.edu/blog/fixgov/2017/03/0 8/on-the-aca-watch-interest-groups-too/

[21] Weller, C. (2018). Working-Class Families Are Getting Hit From All Sides. Retrieved October 01, 2020, from

https://www.americanprogress.org/issues/economy /reports/2018/07/26/453841/working-classfamilies-getting-hit-sides/ 